\title{
The Effectiveness of Audio-Visual Education on Lactation Management and Chocking in Mother with Baby in Pandemic Time Covid-19
}

\author{
Heru Suwardianto ${ }^{1,2,3}$, Rimawati $^{3}$ \\ ${ }^{1}$ Associate Lecturer, Certified Expertise Critical Care (CECC), ${ }^{2}$ Indonesian Critical Care Nurses Association \\ (ICCNA), ${ }^{3}$ Baptist Hospital Health Collage in Kediri, Jl, Mayjend Panjaitan, No. 3B Kediri City, \\ Jawa Timur Indonesia
}

\begin{abstract}
Many mothers with babies who do not give exclusive breastfeeding and do not understand prevention efforts when the baby is choking, so that mothers need to understand lactation management to optimize the purpose of exclusive breastfeeding, and need to equip themselves in preventive management when the baby is choking. The research objective was to determine the effectiveness of lactation management education and management of choking in mothers with babies in East Java Indonesia.
\end{abstract}

The research method was a pre-experimental pretest-posttest design. The population was all mothers with babies in Kediri City East Java Indonesia. The sample consisted of 30 respondents using the incidental sampling technique. The independent variables were lactation management education and the choking in babies. The dependent variable was Knowledge and Skills. The research instrument used a questionnaire to use google form and Youtube. Data were collected and statistical tests were performed using the Wilcoxon test with $\alpha<0.05$.

The results showed that most respondents were infants aged 11-15 months (40\%), maternal age was 23 years old (30\%), had two babies (60\%), body weight $10-11 \mathrm{Kg}(30 \%)$, complete immunization (90\%), but $10 \%$ of infants are not immunized. All infant respondents receive exclusive breastfeeding and also regularly attend Posyandu. The results of the Wilcoxon statistical test on the knowledge variable obtained a $\mathrm{Z}$ value of $-4.8(>1.96)$ with a $\mathrm{P}$-value $=0.000$ and the choking treatment variable with a $\mathrm{Z}$ value of $-4.6(>1.96)$ with a P-value $=0.000$ which means there is a significant effect of Audio-Visual Education on Lactation Management and Choking in Mothers with Babies during the Covid-19 Pandemic on the knowledge and improvement of choking management skills in respondents.

Effective education is provided to increase knowledge and skills in the management of choking in infants. Prevention is more important in reducing the morbidity of cases related to nutrition and the incidence of choking in infants.

Keyword: Audio-visual Education, Lactation, Chocking, Mother with baby.

\section{Introduction}

Lactation management is an effort or means made to achieve successful breastfeeding. One of the successes of breastfeeding is breastfeeding techniques. Incorrect breastfeeding techniques cause pain and blisters on the nipples because the baby does not feed until the breast areola, if he only feeds on the nipples, the baby will get a little breast milk. After all, the gums do not press on the lactiferous and the mother will feel pain due to blisters on the nipples ${ }^{1}$. Mothers can study lactation management as part of an effort to prepare for labor and breastfeeding so that complications and things that hinder the breastfeeding process can be prevented ${ }^{2}$. A mother after giving birth is obliged or expected to 
breastfeed her baby, this is also believed by the existing culture in the community that it is perfect to be a mother if she can conceive, give birth and breastfeed ${ }^{1}$. Obstetricians must take action to safeguard perinatal mental health ${ }^{3}$. The ability to provide support and to protect our breastfeeding mothers becomes extremely difficult where the virus is rampant ${ }^{4-7}$ Mother's milk is the best life fluid that is needed by babies. Mother's milk contains various substances that are important for the growth and development of babies and according to their needs, but not all mothers want to breastfeed their babies for various reasons, for example, fear of fat, busyness, saggy breasts, and so on, some mothers want to breastfeed their babies, but there are many obstacles, usually, breast milk does not want to come out or the production is not smooth $^{8}$. In the Covid-19 pandemic phenomenon that is often found in the community when breastfeeding mothers often have more severe problems due to the mother's lack of knowledge in proper breastfeeding techniques, this can affect the fulfillment of baby nutrition because they do not get optimal nutrition and can also cause pain. blisters, and redness in the mother because the baby is not feeding using improper technique.

The Pandemic COVID-19 is spreading throughout the world and has increased sharply in the number of infections, the number of pregnant women and children with COVID-19 continues to rise ${ }^{9,10}$. Maternal age at the time of COVID-19 in Wuhan was between 29-34 years, with clinical manifestations of fever (86\%), cough (14\%), and shortness of breath (14\%) ${ }^{10}$. According to a study in Dhaka Bangladesh on 1,667 infants for 12 months, the results showed that exclusive breastfeeding can reduce the risk of death from acute respiratory infections and diarrhea. Providing exclusive breastfeeding for 6 months is recommended by international guidelines which are based on scientific evidence about the benefits of breast milk for babies, mothers, families, and country ${ }^{8}$. Based on the results of research by Susan Narula, (2015) on the Relationship between Knowledge Level and Mother's Work with the Success of Lactation Techniques in Breastfeeding Mothers, it shows that most $(80.4 \%)$ breastfeeding mothers fail to perform lactation techniques, (64.7\%) breastfeeding mothers have a low level of knowledge and most (80.4\%) breastfeeding mothers have jobs. The COVID-19 has ramifications for the delivery of newborn nutrition ${ }^{11-13}$. The factors that influence the process of breastfeeding mothers with infants aged 0-6 months, it is shown that
$47 \%$ of mothers show poor breast conditions, $55 \%$ of mothers show poor breastfeeding techniques. Based on the results of observations on breastfeeding mothers on February 10, 2020, at Puskesmas Pesantren Kediri City, the results obtained from 10 breastfeeding respondents, 6 respondents were not capable of breastfeeding techniques by $60 \%$, and 2 respondents who were less capable in breastfeeding techniques by $20 \%$, as well as 2 respondents who are capable of breastfeeding techniques by $20 \%$. The results of the pre-study showed that the problems that occurred in breastfeeding mothers were a pain in $40 \%$ for 4 respondents, $10 \%$ blisters in 1 respondent, and $10 \%$ redness in 1 respondent, and without complaint $40 \%$ in 4 respondents.

Mothers who have babies aged 0-6 months are obliged to provide exclusive breast milk. Exclusive breastmilk is that babies are only given breast milk, without additional fluids such as formula milk, oranges, honey, tea water, water, and without additional solid foods such as bananas. papaya, milk porridge, biscuits, rice porridge, and team ${ }^{1}$. Breastfeeding on time is not enough, not infrequently, failures in breastfeeding, one of which is due to lack of or absolutely no experience and knowledge about how to breastfeed properly. The ability and willingness of a mother to breastfeed are based on a level of knowledge which is a learning process that can produce the expected behavior changes. Giving breast milk alone without any complementary food until the baby is six months old will have tremendous benefits for the development and growth of the baby in addition to increasing the bond of affection between mother and baby. When breastfeeding in public amenities, mothers can wear masks or cloth face coverings to protect themselves, while their infants cannot wear any respiratory protection to avoid direct exposure to the indoor air ${ }^{14}$. The fulfillment of breast milk for infants aged 0-6 months is less effective. This is influenced by the lack of knowledge of mothers in breastfeeding techniques for their babies. Breastfeeding techniques are a way of providing ideal food for the growth and development of the baby, if the mother does not provide proper breastfeeding techniques then the impact on the mother is such as pain, blisters or redness caused by the baby not feeding until the breast areola, while the impact that can occur if babies do not get optimal nutrition from breastfeeding, including the baby's weight does not increase, and babies often whine because they are not satisfied.

The correct breastfeeding technique is necessary 
so that both the baby and the mother feel comfortable and the baby can get the most from breastfeeding. Management of Choking also needs to be properly educated for mothers with babies. Correct breastfeeding techniques can also be useful in reducing infant mortality due to improper breastfeeding positions. Every mother who has a baby needs to know about the correct breastfeeding technique to achieve optimal baby nutrition. Support from nurses and families is very influential in giving breast milk. Nurses can put more emphasis on counseling about correct breastfeeding techniques to prevent common problems that arise such as blisters, pain, and mothers are reluctant to breastfeed because breastmilk does not come out using leaflets and questions and answers so that families and patients can know the importance of breastfeedingin babies.

\section{Method}

Method werea pre-experimental pretest-posttest design. This research provides visual education through google form and also videos embedded in Youtube by researchers. The questionnaire is also placed on the google form, the assessment uses the Linkert scale. The independent variables of the study were lactation management education and the management of choking babies. The dependent variable of this research is Knowledge and Skills. The study population was all mothers with babies in the Pesantren District of Kediri City. The research sample consisted of 30 respondents. This research uses the incidental sampling technique. Incidental Sampling in the technique of determining the sample based on chance, that is anyone who accidentally meets the researcher can be used as a sample if it is considered that the person who happened to be met is suitable as the data source. How to collect research data using a google form link containing video and uploaded to Youtube. Respondents by accessing Google Form received audio-visual education and were also able to directly evaluate their understanding of lactation management and management of choking in infants. The questionnaire link is given to cadres to be continued and given to mothers with babies. The questionnaire contains videos of lactation management and management of choking infants. The sample size obtained was 30 respondents. This study has a permit from the agency and got an Ethics Clearance. Data were collected and statistical tests were performed using the Wilcoxon test with $\alpha<0.05$. Ethical Clearance in Chakra Brahmanda
Lentera Institute Indonesia with Number 010/09/VII/ EC/KEPK/Lemb.Candle/2020.

\section{Results}

Table 1. Demographic

\begin{tabular}{|c|c|c|}
\hline Data & Frequency & Percentage \\
\hline \multicolumn{3}{|l|}{ Age of babies } \\
\hline $1-5$ months & 9 & 30.0 \\
\hline 6-10 months & 6 & 20.0 \\
\hline $11-15$ months & 12 & 40.0 \\
\hline$>15$ months & 3 & 10.0 \\
\hline \multicolumn{3}{|l|}{ Age of Mothers } \\
\hline 23.00 & 9 & 30.0 \\
\hline 24.00 & 3 & 10.0 \\
\hline 25.00 & 6 & 20.0 \\
\hline 28.00 & 3 & 10.0 \\
\hline 32.00 & 6 & 20.0 \\
\hline 33.00 & 3 & 10.0 \\
\hline \multicolumn{3}{|l|}{ Number of Children } \\
\hline One & 12 & 40.0 \\
\hline Two & 18 & 60.0 \\
\hline \multicolumn{3}{|l|}{ Infant Weight (Kg) } \\
\hline $7 \mathrm{Kg}$ & 6 & 20.0 \\
\hline $8 \mathrm{Kg}$ & 6 & 20.0 \\
\hline $10 \mathrm{Kg}$ & 9 & 30.0 \\
\hline $11 \mathrm{Kg}$ & 9 & 30.0 \\
\hline \multicolumn{3}{|l|}{ Immunization } \\
\hline Complete & 3 & 10.0 \\
\hline Incomplete & 27 & 90.0 \\
\hline Exclusive Breastfeeding & 30 & 100.0 \\
\hline Routine to Posyandu & 30 & 100.0 \\
\hline
\end{tabular}

The results of the study were obtained from 30 respondents of mothers with babies who were respondents during the COVID-19 Pandemic. The results showed that most respondents were infants aged 11-15 months $(40 \%)$. The results showed that most of the mothers were 23 years old (30\%). Most of the respondents had two babies (60\%). Respondents Babies weigh at most 10-11 $\mathrm{kg}(30 \%)$. Respondents Babies have the majority have complete immunization $(90 \%)$, but $10 \%$ of infants are not immunized. All infant respondents receive exclusive breastfeeding and also regularly attend Posyandu. 
Table 2. Statistical Test

\begin{tabular}{|l|c|c|c|c|c|c|c|c|c|}
\hline \multirow{2}{*}{ Variable } & \multicolumn{2}{|c|}{ Before } & \multicolumn{2}{c|}{ After } & \multicolumn{3}{c|}{ Ranks } & \multicolumn{2}{c|}{ Wilcoxon } \\
\cline { 2 - 10 } & $\mathbf{X} \pm$ SD & $\begin{array}{c}\text { Shapiro- } \\
\text { Wilk }\end{array}$ & $\mathbf{X} \pm$ SD & $\begin{array}{c}\text { Shapiro- } \\
\text { Wilk }\end{array}$ & Negative & Positive & Ties & $\mathbf{Z}$ & p-Value \\
\hline $\begin{array}{l}\text { Knowledge of Lactation } \\
\text { Management }\end{array}$ & $5.1 \pm 0.6$ & 0.000 & $8.8 \pm 0.8$ & 0.001 & 0 & 30 & 0 & $-4,826$ & 0,000 \\
\hline Choking Management & $4,8 \pm 0,6$ & 0,000 & $6,7 \pm 9,4$ & 0,003 & 2 & 27 & 1 & $-4,563$ & 0,000 \\
\hline
\end{tabular}

Based on the results of the study, it was found that the average knowledge before the Audio-Visual Education on Lactation Management and Choking in Mothers with Babies During the Covid-19 Pandemic, it was 5.1 and after education, it was 8.8. Based on the results of the study, it was found that the average choking treatment before the Audio-Visual Education on Lactation Management and Choking in Mothers with Babies during the Covid-19 Pandemic was 4.8 and after education was 6.7. The results of the normality test using Shapiro-Wilk showed that all data $<0.05$, which means that all data groups are not normal, so the statistical test is reduced to Wilcoxon. The results of the Wilcoxon statistical test on the knowledge variable obtained a $\mathrm{Z}$ value of $-4.8(>1.96)$ with $\mathrm{P}$-value $=0.000$, which means that there is a significant effect Audio-Visual Education on Lactation Management and Choking Baby Management in Mothers with Babies during the COVIDPandemic Period 19 towards increasing knowledge of respondents. The results of the Wilcoxon statistical test on the choking management variable obtained a $\mathrm{Z}$ value of $-4.6(>1.96)$ with $P$-value $=0,000$ which means there is a significant effect Audio-Visual Education on Lactation Management and Choking Baby Management in Mothers with Babies during the COVID Pandemic -19 towards the improvement of choking management skills in respondents.

\section{Discussion}

Lactation management is an effort or method made to achieve breastfeeding success. One of the successes of breastfeeding is breastfeeding techniques. Incorrect breastfeeding techniques cause pain and blisters on the nipples because the baby does not feed until the breast areola, if he only feeds on the nipples, the baby will get a little breast milk. After all, the gums do not press on the lactiferous and the mother will feel pain due to blisters on the nipples. Breastfeeding technique is a way that is second to none in providing ideal food for healthy growth and development of infants and has a unique biological and psychological impact on the health of mothers and babies. Breastfeeding techniques are needed so that babies and mothers feel comfortable and that babies can get the most benefit from breastfeeding. The correct technique of breastfeeding is how to give breast milk to the baby with the correct attachment and position of the mother and baby. Breastfeeding is a way that is second to none in providing the ideal food for the growth and development of a healthy baby.

Based on the results of the study, it was found that Audio-Visual Education on Lactation Management and Management of Choking Babies in Mothers with Babies during the Covid-19 Pandemic had an impact on choking management skills in infants. The baby was associated with increased risk of choking and the highest frequency of choking on finger foods occurred in those who were given finger foods the least often ${ }^{15-17}$. This shows that the education provided can be used as a preventive in management efforts if choking occurs in infants $^{18,19}$. Based on the results of the study, most of the mothers who had fewer breastfeeding techniques were mothers who did the breastfeeding technique where the steps were partially carried out and some steps were not carried out. The steps that are not taken by the mother are that the baby is not stimulated to open the mouth by touching the cheek with the nipple after the baby is fed, the suction is not released in the right way, namely by inserting the mother's little finger into the baby's mouth, after breastfeeding, milk The mother did not remove a little which was then smeared on the nipple and areola, and the mother also did not check the condition of the breast for injuries or cracks after breastfeeding. In breastfeeding techniques with steps that are not taken by the mother, the mother may have become accustomed to not doing it because the breastfeeding time is not right, and the baby often cries ${ }^{20,21,30,31,22-29}$. The steps taken in part are that the mother does not wash her hands before the act of breastfeeding, the mother does not sit or lie 
down casually, the baby's head is not in the arch of the mother's elbow and sometimes the baby's head looks up, the baby's stomach is not attached to the mother's stomach, the mother only turns her head babies, the mother only holds the nipple or areola without supporting the entire breast, the baby is not stimulated to open his mouth when breastfeeding, most areola does not enter the baby's mouth, only the nipple, after breastfeeding the mother also does not release the baby's suction using the little finger, the mother does not burp the baby in the right way and the mother does not check the condition of the breast after breastfeeding.

In techniques that are carried out with partial steps in the breastfeeding technique, some techniques are carried out correctly in some respondents, namely before breastfeeding the mother washes her hands, the baby's head is located on the arch of the elbow and the head does not look up, and the baby's stomach is attached to the mother's stomach. The results showed that mothers who were 23 years of age with fewer breastfeeding techniques, but mothers often said they forgot the steps that had to be taken and the age difference was too far about the breastfeeding technique given to the previous child. According to Roesli (2000), in Astutik, 2014, mothers who have babies aged 0-6 months are obliged to provide exclusive breast milk. Exclusive Breastfeeding means that babies are only given breastmilk, without the addition of other fluids such as formula milk, oranges, honey, tea water, water, and without additional solid foods such as bananas, papaya, milk porridge, biscuits, rice porridge, and team. Mother's education with high school education level will affect breastfeeding techniques for babies who are more than 5 months old, but from the results of the research, the mother's baby continues to apply breastfeeding techniques that are not following the right steps this can be due to a lack of knowledge and experience. owned by the mother. This is followingAstutik's theory, in 2014 a mother after giving birth is obliged or expected to breastfeed her baby, this is also believed by the existing culture in a society that it would be perfect to be a mother if she was able to conceive, give birth, and breastfeeding. Where, if seen from Sunarsih's theory, 2013 Mother's Milk is the best fluid of life that is needed by babies. Mother's milk contains various substances that are important for the growth and development of babies and according to their needs, but not all mothers want to breastfeed their babies for various reasons, for example, fear of fat, busyness, saggy breasts, and so on, some mothers want to breastfeed their babies, but there are many obstacles, usually mother's milk does not come out or the production is not smooth.

Sufficient breastfeeding technique for mothers is mothers who do the technique with the right steps, and do the technique with partial steps, where the steps are taken correctly are the mother washing her hands before feeding, the mother looking at the baby with great affection, after the baby opens his mouth, quickly the mother brings the breast closer and most of the serial enters the baby's mouth, the baby is slung in the right way, that is, the baby is held upright against the mother's shoulder then the mother gently pats the baby's back. However, it was also found that several techniques were not used, namely, the mother did not stimulate the baby to open his mouth when he was going to be breastfed, the mother did not release the baby's suction with her little finger after breastfeeding, and the mother did not check the condition of the breast after breastfeeding $5,32,33$. This can be proven in terms of the existing phenomena or problems if the respondent has problems with pain and blisters. After all, the baby does not breastfeed until the breast is acerola, if he only feeds on the nipple then the baby will get a little breast milk because the gums do not press on the lactiferous and the mother will feel pain due to blisters on the nipple. Insufficient breastfeeding techniques, the results show that working mothers do breastfeeding techniques in the right steps, it does not rule out that working mothers will affect the time of breastfeeding given to babies, a work schedule that cannot be controlled by the respondent. There are several views from experts on the family. A family consisting of individuals who are joined together by the bonds of marriage, blood, adoption, and live in the same household. While on the other hand, the family is defined as a part of a society whose role is very important to form a healthy culture. In the research results, it was found that most of the breastfeeding techniques lived together with husband and family so that living together in one house with the husband and the respondent's family would feel psychologically supported to help and support in the act of breastfeeding so that the respondent had sufficient knowledge about the position of breastfeeding. adequate nutritional status, how to stimulate breast milk and care for breasts, so that respondents have confidence, are relaxed in breastfeeding and are not stressed. Family social support provides physical and psychological comfort, reducing the tendency for events that can cause stress . 


\section{Conclusion}

Based on the results of the study, it was found that the mean of knowledge before the Audio-Visual Education on Lactation Management and Management of Choking Babies in Mothers with Babies during the Covid-19 Pandemic which means that there is a significant effect Audio-Visual Education on Lactation Management and Choking Baby Management in Mothers with Babies during the COVID-Pandemic Period 19 towards increasing knowledge of respondents. The results of the Wilcoxon statistical test on the choking management variable which means there is a significant effect AudioVisual Education on Lactation Management and Choking Baby Management in Mothers with Babies during the COVID Pandemic -19 towards the improvement of choking management skills in respondents.

Acknowledgments: We thank the Indonesian Ministry of Science, Research, Technology, and Higher Education (RISTEKDIKTI RI) for the 2019 Research Grant and implementation in 2020. We thank all parties and all the research respondents.

Ethical Clearance: Ethical Clearance has taken form from the Chakra Brahmanda Lentera Institute with letter number 010/25/V/EC/KEPK/Lemb.Candle/2020.

Source of Funding: This research is the result of a research grant from the Ministry of Education and Technology in 2019 and Implementation in 2020.

\section{References}

1. Astutik. Payudara dan Laktasi. Jakarta: Salemba Medika, 2014.

2. Monika. Buku Pintar ASI dan Menyusui. Jakarta: PT. Mizan Publika, 2014.

3. Ceulemans M, Hompes T, Foulon V. Mental health status of pregnant and breastfeeding women during the COVID-19 pandemic: A call for action. Gynecol Obstet 2020; 1: 1.

4. Marinelli KA. International Perspectives Concerning Donor Milk Banking During the SARS-CoV-2 (COVID-19) Pandemic. J Hum Lact 2020; $1: 1$.

5. Julianne Williams. The Importance of Continuing Breastfeeding during Coronavirus Disease-2019: In Support of the World Health Organization Statement on Breastfeeding during the Pandemic. Eur Paediatr Assoc 2020; 223: 1.
6. Rodrigues C, Baia I, Domingues R, et al. Pregnancy and breastfeeding during COVID-19 pandemic: A systematic review of published pregnancy cases. Medrxiv 2020; 1: 1 .

7. Dandona R. Maintaining safety and service provision in human milk banking: a call to action in response to the COVID-19 pandemic. The Lancet Child 2020; 1 : 1 .

8. Sunarsih. Asuhan Kebidanan Pada Ibu Nifas. Jakarta: Salemba Medika, 2013.

9. Zeng L, Xia S, Yuan W, et al. Neonatal Early-Onset Infection With SARS-CoV-2 in 33 Neonates Born to Mothers With COVID-19 in Wuhan, China. JAMA Pediatr. Epub ahead of print 2020. DOI: 10.1001/jamapediatrics.2020.0878.

10. $\mathrm{Yu} \mathrm{N}, \mathrm{Li} \mathrm{W}$, Kang Q, et al. Clinical features and obstetric and neonatal outcomes of pregnant patients with COVID-19 in Wuhan, China: a retrospective, single-centre, descriptive study. Lancet Infect Dis 2020; 20: 559-564.

11. Sachdeva. Ensuring Exclusive Human Milk Diet for All. Eur PMC 2020; 1: 1.

12. Salvatore CM, Han J-Y, Acker KP, et al. Neonatal management and outcomes during the COVID-19 pandemic: an observation cohort study. Lancet Child Adolesc Heal. Epub ahead of print 2020. DOI: https://doi.org/10.1016/S2352-4642(20)30235-2.

13. Moro GE, Bertino E. Breastfeeding, Human Milk Collection and Containers, and Human Milk Banking: Hot Topics During the COVID-19 Pandemic. J Hum Lact 2020; 1: 1.

14. Wang X, Han J, Lichtfouse E. Unprotected mothers and infants breastfeeding in public amenities during the COVID-19 pandemic. Environ Chem Lett. Epub ahead of print 2020. DOI: 10.1007/s10311020-01054-1.

15. Brown. No difference in self-reported frequency of choking between infants introduced to solid foods using a baby-led weaning or traditional spoonfeeding approach. J Hum Nutr Diet 2017; 31: 1.

16. Dogan E, Yilmaz G. Baby-led complementary feeding: Randomized controlled study. Pediatr Int 2018; 60: 1 .

17. Pavitt MJ, Nevett J, Swanton LL, et al. London ambulance source data on choking incidence for the calendar year 2016: an observational study. Respir Epidemiol 2017; 4: 1. 
18. Lau C. Breastfeeding Challenges and the Preterm Mother-Infant Dyad: A Conceptual Model. Breastfeed Med 2017; 13: 8-17.

19. Gomes-Filho IS, Pinheiro SMS, Vieira GO, et al. Exclusive breast-feeding is associated with reduced pacifier sucking in children: Breast-feeding and pacifier-sucking habit. J Am Dent Assoc 2019; 150: 940-947.

20. Kritzinger A, Pottas L. Breastfeeding and swallowing in a neonate with mild hypoxicischaemic encephalopathy. South African J Commun Disord 2017; 64: 1-7.

21. Sriraman NK. The Nuts and Bolts of Breastfeeding: Anatomy and Physiology of Lactation. Curr Probl Pediatr Adolesc Health Care 2017; 47: 305-310.

22. Suwardianto H, Selvia D. Buku Ajar Keperawatan Kegawatdaruratan (Perspektif, Konsep, Prinsip, dan Penatalaksanaan Kegawatdaruratan). Surabaya: PT. REVKA PETRA MEDIA, 2015.

23. Suwardianto H, YC A. Kemandirian Fungsional Lansia Diabetes Melitus Di Kelurahan Bangsal Kota Kediri. J STIKES RS Baptis Kediri; 9.

24. Suwardianto H, Richard SD. Asuhan Keperawatan Kegawatdaruratan dan Penatalaksanaan Tindakan Kegawatdaruratan. Nganjuk: CV Adjie Media Nusantara, 2017.

25. Suwardianto H. Deep breathing relaxation as therapy to decrease blood preassure on hypertension patients. Proc Fac Nurs Airlangga fourd Int Nurs Conf Improv Qual Nurs Care Though Nurs Res Innov 2013; 1: 1-12.

26. Suwardianto H. Tardive dyskenesia, motor activity, sedation scale, dan cardiac workload pasien IPI pada pemberian analgesik di instalasi perawatan intensif RS. baptis kediri. Keperawatan Krit Penelit Hibah YBI.

27. Yusiana MA, Suwardianto H. The Effectiveness of Deep Breathing And Slow Stroke Back Massage To Decrease The Blood Pressure On A Patient With Hypertension. Indones Nurs J Educ Clin 2018; 1: 31-39.

28. Suwardianto H, Prasetyo A, Utami RSu. Physical Function-Tardive Dyskenesia (PATD) on Critical Patients in Intensive Care Unit. J Ners; 12. Epub ahead of print 2017. DOI: http://dx.doi. org/10.20473/jn.v12i2.4504.

29. Suwardianto H, Rimawati. Explicit Instruction Model (EIM): Daily Training Emergencies Preparedness (DTEP) Toward Skills of Participants the Youth Red Cross. Conf 2nd Jt Int 2018; 2: 403410.

30. Erwin PA, Suwardianto H, Yuliani N. 5th Octave Music Therapy Menurunan Tekanan Darah Terhadap Penderita Hipertensi. J Penelit Keperawatan; 1.

31. Suwardianto H, Sari D. Environmental Factors of Sleep Hygiene That Influence The Level of Pain on Criticall ill Patients in Intensive Care Unit. Str J Ilm Kesehat; 9. Epub ahead of print 3 May 2020. DOI: 10.30994/sjik.v9i1.266.

32. Anderson PO. Drugs of Abuse During Breastfeeding. Breastfeed Med 2018; 13: 405-407.

33. Islam MJ, Baird K, Mazerolle P, et al. Exploring the influence of psychosocial factors on exclusive breastfeeding in Bangladesh. Arch Womens Ment Health 2017; 20: 173-188. 